University of Nebraska - Lincoln

DigitalCommons@University of Nebraska - Lincoln

2009

\title{
Loci sigilli and American Indian treaties: Reflections on the creation of volume 2 of Kappler's Indian Affairs: Laws and Treaties
}

Charles D. Bernholz

University of Nebraska-Lincoln, cbernholz2@unl.edu

Sheryl Heidenreich

University of Nebraska Kearney

Follow this and additional works at: https://digitalcommons.unl.edu/libraryscience

Part of the Library and Information Science Commons

Bernholz, Charles D. and Heidenreich, Sheryl, "Loci sigilli and American Indian treaties: Reflections on the creation of volume 2 of Kappler's Indian Affairs: Laws and Treaties" (2009). Faculty Publications, UNL Libraries. 210.

https://digitalcommons.unl.edu/libraryscience/210

This Article is brought to you for free and open access by the Libraries at University of Nebraska-Lincoln at DigitalCommons@University of Nebraska - Lincoln. It has been accepted for inclusion in Faculty Publications, UNL Libraries by an authorized administrator of DigitalCommons@University of Nebraska - Lincoln. 


\title{
Loci sigilli and American Indian treaties: Reflections on the creation of volume 2 of Kappler's Indian Affairs: Laws and Treaties
}

\author{
Charles D. Bernholz, Love Memorial Library, University of Nebraska-Lincoln, Lincoln, NE 68588, USA \\ Sheryl Heidenreich, Calvin T. Ryan Library, University of Nebraska Kearney, Kearney, NE 68849, USA \\ Corresponding author - C. Bernholz, fax 402 472-5131, email cbernholz2@unl.edu
}

\begin{abstract}
The presence- or absence- of locus sigilli "[L.S.]" or "[SEAL]" indicators, to validate the signatures in those texts of American Indian treaties collated by Charles J. Kappler in his Indian Affairs: Laws and Treaties, is examined. The results of this inquiry suggest that Kappler spent far more time examining the original treaty documents than Deloria and DeMallie proposed in their Documents of American Indian Diplomacy: Treaties, Agreements, and Conventions, 1775-1979.
\end{abstract}

Keywords: American Indian treaties, Charles J. Kappler

In their publication Documents of American Indian Diplomacy: Treaties, Agreements, and Conventions, 1775-1979, Vine Deloria and Raymond J. DeMallie questioned the process by which Charles J. Kappler created volume 2 of his Indian Affairs: Laws and Treaties. ${ }^{1}$ They suggested in their Introduction that "[i]n short, after surveying the federal records dealing with Indian treaties, one can only conclude that the list of treaties in Kappler's represents those documents on file at the Bureau of Indian Affairs when Charles Kappler and his clerks began their work. It appears that they simply took several filing drawers filled with documents to the printer" (1999, p. 3).

Deloria and DeMallie's conclusion offers, on the one hand, a critique of Kappler's vigilance for any other outstanding treaties, a claim substantiated by the number of alternative documents proposed in their own two-volume publication. On the other hand, their deduction may be regarded as a direct challenge to the protocol used to select the appropriate texts for inclusion in Indian Affairs. The short answer to this challenge-an expansion will be presented below - is that Kappler limited his scope to only those American Indian treaties recognized by the Department of State, and then compiled from these only those that were created with the federal government. Taken together, however, the declaration by Deloria and DeMallie offers a perception that Kappler's work was both incomplete and assembled with marked disregard to the original instruments. This article will demonstrate that these alleged shortcomings were inappropriately attributed to Kappler.
In general, rather little has been written about Charles J. Kappler (1868-1946). ${ }^{2}$ He was a life-long resident of Washington, DC; graduated from the Law School at Georgetown University with his LL.B degree in 1896 and then an LL.M the following year; and admitted to the Bar in 1896 (New Lawyers Admitted to Bar, 1896; Kappler, 1896, 1901). Among other responsibilities within the federal government, he served as Clerk of the Senate Committee on Indian Affairs for the 57th and 58th Congresses, between 1901 and 1905. In the year 1902, a resolution was proposed to form a collation of pertinent federal Indian materials (Compilation on Indian Affairs, 1902a, 1902b). ${ }^{3}$ Kappler, in response-beginning in 1903 and, after he left federal employment and practiced law, continuing until 1941-produced his five-volume Indian Affairs: Laws and Treaties. Volume 2 was devoted to the treaties created between the tribes and the federal government.

When Kappler began his work, the treaty texts were easily accessible, since almost all of the recognized documents were published by then in the Statutes at Large. Treaty making with the tribes had terminated in 1871 (16 Stat. 544, 566), and these instruments were published in Statutes volume numbers 7, 9 through 16, and 18. In an 1845 letter to Little and Brown, the publishers of the Statutes, Representative Robert C. Winthrop (Whig-Massachusetts) noted in the first volume of the series that this compilation "embraces all the laws which have been enacted since the foundation of our government, Private as well as Public, District as well as National, the obsolete and repealed as well as those now in

${ }^{1}$ V. Deloria and R. J. DeMallie, Documents of American Indian Diplomacy: Treaties, Agreements, and Conventions, University of Oklahoma Press, Norman, OK (1999).

${ }^{2}$ Bernholz and Weiner (2008) have examined Kappler's life outside of this Indian Affairs task.

${ }^{3}$ Three earlier ensembles were: Indian Treaties, and Laws and Regulations Relating to Indian Affairs (1826); Treaties Between the United States of America and the Several Indian Tribes, From 1778 to 1837 (1837); and A Compilation of All the Treaties Between the United States and the Indian Tribes Now in Force as Laws (1873). The resolution was submitted on 19 May 1902 by Senator William Morris Stewart of Nevada, for whom Kappler had worked during the previous decade. The next day, the final version of the resolution read: "Resolved, That the Committee on Indian Affairs is hereby authorized to have prepared for the use of the Senate a compilation of all treaties, laws, and Executive orders now in force relating to Indian affairs" (Compilation on Indian Affairs, 1902b, p. 5665). 
force. It includes, also, all our Treaties with foreign governments and with the Indian tribes.... There would thus seem nothing left to be desired for the completeness of our National Code" (1 Stat. vi). Since that time, the Statutes have served as the official source for the acknowledged texts of American Indian treaties with the federal government.

Kappler's entire task was contained in two volumes, subtitled Laws and Treaties, respectively. The first edition of Treaties was published in 1903, in Serial Set volume 4254, containing 832 pages (Kappler, 1903b). In the set's preface dated 1 February 1903, he declared:

"[a]n accurate compilation of the treaties, laws, Executive orders, and other matters relating to Indian affairs, from the organization of the Government to the present time, has been urgently needed for many years, and its desirability has been repeatedly emphasized by the Commissioner of Indian Affairs in his annual reports to Congress... Owing to the great mass of matter to be examined and edited, much caution and judgment had to be exercised to keep the volumes within bounds... The general form of the Statutes at Large has been followed, as being familiar to publicists and lawyers and best suited to meet practical requirements" (Kappler, 1903a, p. iii).

The following year, in response to a series of concurrent resolutions (Treaties, laws, etc., relating to Indian Affairs, 1903a, 1903b, 1903c, 1903d), the same treaty materials were republished as a 1099 page second edition in Serial Set volume 4624, with indications of the original signatures and any additional text. Here, in the new suite's preface of 2 March 1904, Kappler stated:

"[t]he new edition has afforded the compiler an opportunity to make such typographical and other corrections as were discovered in the first print, to insert several treaties and documents which were heretofore unobtainable, and to add the signatures subscribed to each treaty which were omitted in the first edition to save space" (Kappler, 1904a, p. iii).

An acknowledgment at the end of the preface revealed a coworker on the project: "James D. Finch, jr., assistant clerk of the Senate Committee on Indian Affairs."

Over the years, then, there has never been any doubt that Kappler used these final Statutes entries as the main source of his Treaties compilation. ${ }^{5}$ It is therefore of sustained interest to examine his versions of these documents, especially since his volume reveals some significant changes that occurred between the original signing process and the final Statutes at Large version of these treaties.

Primarily, there are a number of differences between the formats of the treaties brought before the Senate and those found in Indian Affairs. He also incorporated more subtle adjustments, such as different dollar amounts, that are only unveiled through an assessment of the treaty text in the Statutes. Kappler made neither of these two points clear in his work and it is only through the inspection of footnotes reproduced from the Statutes entry, or through the examination of individual Articles, that some Senate changes may be identified.
These variations are quite apparent when volume 7 of the Statutes is studied. This single volume contains the final texts of all but twelve of the first 243 treaties, or over $60 \%$ of the entire array of 375 recognized instruments (Ratified Indian Treaties, 1722-1869, 1966). Of particular importance in Treaties are the careful textual indications made by Kappler for those Statutes phrases or even entire articles that were "Stricken out" or that bear the declaration "Stricken out by Senate" during the ratification sequence. Eight such examples ${ }^{6}$ occur in this single Statutes volume; across the entire suite, more than a dozen similarly adjusted treaties were included. These attributes suggest that Kappler spent a considerable amount of time examining and re-checking the Statutes at Large during the preparation of the second volume of Indian Affairs. The Statutes at the turn of the twentieth century offered all the accepted legal texts of the original events consummated with the federal government, save those for ratified treaty numbers 19, 28, and 44 that were published in the American State Papers: Indian Affairs, and for the Treaty of Fort Laramie with Sioux, etc., $1851 .{ }^{7}$

As an attorney, Kappler would have had significant experience with, and exposure to, these Statutes. Careful searching of the appropriate texts of all these transactions during the preparation of the composite record requested by the Senate-itself populated by other attorneys-could have been accomplished only through the examination of the original documents themselves, or through their transcriptions found in the Statutes at Large. Any future law, or potential court proceedings, pivoting on the parameters of these dealings, would have demanded the use of the accepted legal text, as revealed in these Statutes. This cautious perspective would be especially relevant for those accords signed by the tribes but subsequently adjusted by Congress, a scenario directly mirrored, for example, by the "Stricken out" treaties. In short, the Statutes were the most conservative and yet robust source for all but a handful of the federally recognized treaties with the tribes. The creation of the initial second Treaties volume in 1903-without signatures-could have been quite easily accomplished by editing out the unneeded portions of the appropriate Statutes at Large content.

\section{The 1904 treaty signature sections}

The addition of the signature sections to the second edition was a significant event. Among other new opportunities-and especially now in combination with the search capability afforded by the digitization of all of Kappler's Indian Affairs: Laws and Treaties volumes by the Oklahoma State University Library (see Holcombe, 2000; Bernholz and Holcombe, 2005)-specific participants could be located; their names in their own languages could be identified; and connections drawn between various treaty events could be more easily established. Perhaps as a reflection of his legal background, Kappler included the "[L.S.]" or locus sigilli ("the place of the seal") indicator to confirm the original signed-andsealed occurrence of these signatures. ${ }^{8}$ In some cases, the analogous marker "[SEAL]," reflecting the physical presence of a wax seal, was employed. Still other documents in volume 2 contain no

\footnotetext{
${ }^{4}$ This relationship is confirmed in the Official Congressional Directory for the fifty-seventh Congress (Halford, 1901, pt. 2, p. 195).

${ }^{5}$ The mixed fidelity with which Kappler's compilation reproduced the contents of the Statutes may be seen in an example of witness names in the signature section of the Treaty with the Seneca and Shawnee, 1832 (Kappler, 1904b, p. 385, http://digital.library.okstate.edu/kappler/Vol2/treaties/sen0383.htm ) and in that of the Statutes (7 Stat. 411, 413). The name "George Herron, Seneca Interpreter" appears in both sources, while "Baptiste Peora, Shawnee Interpreter" and "Baptiste Peoria, Shawnee Interpreter" are in the Statutes and Kappler, respectively. The original treaty has "Batiste Peora."

${ }^{6}$ See the Treaty with the Chippewa, 1833 (Kappler, 1904b, pp. 402-415, http://digital.library.okstate.edu/kappler/Vol2/treaties/chi0402.htm ); the Treaty with the Cherokee, 1835 (pp. 439-449, http://digital.library.okstate.edu/kappler/Vol2/treaties/che0439.htm ); the five 1836 treaties with the Potawatomi (p. 450, http://digital.library.okstate.edu/kappler/Vol2/treaties/pot0450.htm ; p. 457, http://digital.library.okstate.edu/kappler/Vol2/treaties/ pot0457.htm ; pp. 457-458, http://digital.library.okstate.edu/kappler/Vol2/treaties/pot0457a.htm ; pp. 458-459, http://digital.library.okstate.edu/kappler/Vol2/treaties/pot0458.htm ; and p. 459, http://digital.library.okstate.edu/kappler/Vol2/treaties/pot0459.htm ); and the Treaty with the Sioux, 1837 (pp. 493-494, http://digital.library.okstate.edu/kappler/Vol2/treaties/sio0493.htm ).

${ }^{7}$ See these four documents at: a) http://digital.library.okstate.edu/kappler/Vol2/treaties/fiv1027.htm ; b) http://earlytreaties.unl.edu/treaty.00028.html ; c) http://earlytreaties.unl.edu/treaty.00044.html ; and d) http://digital.library.okstate.edu/kappler/Vol2/treaties/sio0594.htm
} 
such legalese, and yet the variability of the presence of this traditional indicator poses a useful tool..$^{9}$

\section{The source and data for this study}

The 1904 edition has been particularly useful since its publication, because it has provided these complete texts in a single, very accessible volume. In total, the tome contains 388 contracts, divided into two sections. A general treaty portion holds 364 of the 375 treaties recognized by the Department of State (Ratified Indian Treaties, 1722-1869, 1966)..$^{10}$ The Appendix holds another two acknowledged items. ${ }^{11}$ The remaining twenty-two items, consisting of seven supplemental and fifteen other Appendix documents, were not studied in this exercise. ${ }^{12}$

Of these 366 documents, five were removed from further analysis. Two were eliminated because their texts were never included in the Statutes at Large. Ratified treaty number 19, the Agreement with the Five Nations of Indians, 1792 (Kappler, 1904b, p. 1027, http:/ / 0-digital.library.okstate.edu.library.unl.edu/kappler/ Vol2/treaties/fiv1027.htm ), appeared only in volume 1 of the American State Papers: Indian Affairs (1832, p. 232). In addition, the Treaty of Fort Laramie with Sioux, etc., 1851 (p. 594, http://0-digital.library.okstate.edu.library.unl.edu/kappler/Vol2/treaties/ sio0594.htm ) was confirmed as a valid instrument only through judicial proceedings at the turn of the twentieth century. Three other documents were either missing or were possibly incorrectly included in the National Archives' Ratified Indian Treaties (1966) microfilm collection used for loci sigilli comparison; ${ }^{13}$ these too were removed from the test corpus. Because of this culling, 361 of Kappler's versions of these instruments qualified for this analysis.

The test data for this study consisted of recording the presence or the absence (scored as 1 or 0 , respectively) of three variables. These components were determined through counts of the incidences of the "[L.S.]" or "[SEAL]" signature indicator as compiled across three publications: the Statutes at Large, the Treaties volume, and from the images of the treaties on the Ratified Indian Treaties microfilm.

\section{General observations}

- Overall, a comparison of the signature sections contained in Kappler's publication with the corresponding ones in the Statutes reveals that there is a limited correspondence between the appearance in Treaties of "[L.S.]" or "[SEAL]" signature indicators and any such markers in the Statutes. The most distinct difference between the presence of the marks in Kappler's publication and the marks in the Statutes texts is found in the occasion counts. The Statutes contain only 103 such symbols in 361 treaties, while Kappler's collation has almost two and one-half times as many, or 249 loci sigilli of some sort, in the same instruments.

- This quantitative difference alone signals that Kappler did not rely exclusively upon the characters shown in the Statutes, and this may be demonstrated quite dramatically by examining only the contents of volume 7 . All but two of the 228 examined documents in that publication have no signature indicators. ${ }^{14}$ Within the remaining array of 226 Statutes instruments without such signals, Kappler did supply one to 150 of these-or over $66 \%$ of volume 7 's contents-in his collation. This strongly implies the use of some other avenue to determine signatory participation.

- One possible alternative source, which might have influenced Kappler's ultimate decisions, may have been the 139 closing paragraphs of these 228 treaties in volume 7 that contain variations of the following: "we hereunto affix our hands and seals" (Treaty with the Choctaw, 1803, pp. 69-70, http://0-digital.library.okstate.edu.library.unl.edu/kappler/Vol2/treaties/ cho0069.htm ); "signed their hands, and affixed their seals" (Treaty with the Seneca, etc., 1831, pp. 327-331, http://0-digital.library.okstate.edu.library.unl.edu/kappler/Vol2/treaties/sen0327.htm ); or "[d]one, and signed and sealed" (Treaty with the Sauk and Foxes, etc., 1830, pp. 305-310, http://0-digital.library.okstate.edu.library.unl.edu/kappler/Vol2/treaties/ sau0305.htm ). This notation is employed sixteen further times in seven of the nine other relevant Statutes volumes for treaties. Those documents without the "signed and sealed" narratives

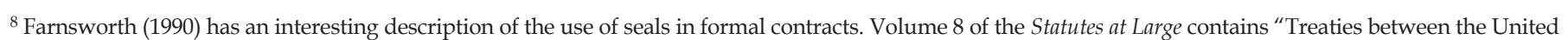
States of America and Foreign Nations, from the Declaration of Independence of the United States to 1845: with notes." The first entry in this international volume is the 1778 Treaty of Alliance Between the United States of America and His Most Christian Majesty (8 Stat. 6); there is an "(L.S.)" appended to the printed name of each signatory. Many American Indian treaties have a ribbon woven along the side of the signature sections as well. This is a continuation of the old validation style where the wax seal was attached to the ribbon rather than to the document itself (see Walker, 1980, p. 1122 and the National Archives of Canada's Finding Aid/Instrument de Recherche No. 2122: MG 19, F 35-Superintendent of Indian Affairs [1997] for British examples). Use of these indicators in negotiations in Canada may be seen in the three volumes of (Indian Treaties and Surrenders, 1891) and (Indian Treaties and Surrenders, 1912).

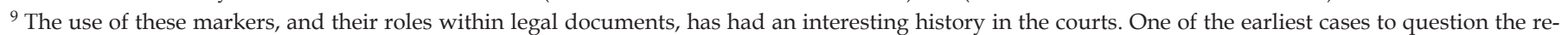
quirement of their presence was Evans' Lessee v. Short (1797), before the Court of Common Pleas of Delaware, in which it was determined that an official locus sigilli was not necessary to prove a certified copy of a land patent. See Norton (1928, pp. 7-10) for a rich discussion. Westlaw returned thirty-five individual proceedings when locus sigilli was used as the search item within the ALLCASES option.

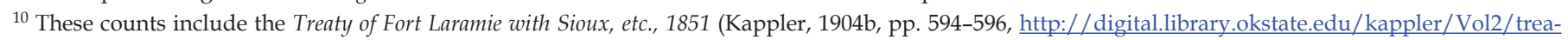
ties/sio0594.htm ) that, while not recognized originally by the Department of State, has since been acknowledged as a valid treaty by the Court of Claims (Moore v. United States, 1897 and Roy v. United States and the Ogallala Tribe of Sioux Indians, 1910). The text of this instrument does not appear in the Statutes at Large. Years after the second case, Kappler added a special section for the Treaty of Fort Laramie, 1851 to his fourth volume (Kappler, 1929, pp. 1065-1081; http://digital.library.okstate.edu/kappler/Vol4/html files/v4p1065b.html ), including an Indian Office memorandum that cited "an exact copy of the whole proceeding regarding this treaty as the same appears in Senate Journal, 1st session, Thirty-second Congress" (p. 1069).

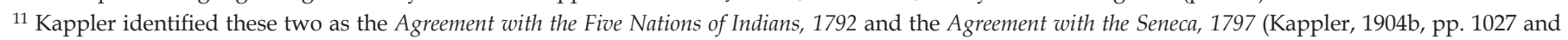
1027-1030, and http://digital.library.okstate.edu/kappler/Vol2/treaties/fiv1027.htm and http://digital.library.okstate.edu/kappler/Vol2/treaties/ sen1027.htm, respectively).

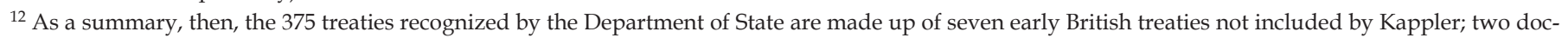
uments found only in the American State Papers: Indian Affairs instead of in the Statutes at Large, and thereby absent from Indian Affairs; the 364 instruments located in the main section of volume 2 of Indian Affairs: Laws and Treaties; and two additional items in its Appendix.

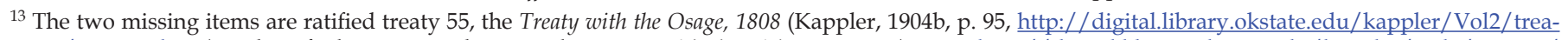
ties/osa0095.htm ) and ratified treaty number 112, the Treaty with the Kickapoo, 1820 (p. 189, http://digital.library.okstate.edu/kappler/Vol2/treaties/ kic0189.htm ). The images of Ratified Indian Treaties, 1722-1869 (1966) show for this pair a) on reel \#3, a title card that states "Treaty No. 55 is Missing," and b) on spool \#5, a remark of "Original treaty missing." Ratified treaty number 109, the Treaty with the Chippewa, 1819, p. 185, http://digital.library.okstate. edu/kappler/Vol2/treaties/chi0185.htm ) begins on the latter microfilm roll with the concern "109(?) Check this. Number not on box." Based on these annotations, the three treaties (ratified treaty number 55, 109, and 112) were eliminated from this study.

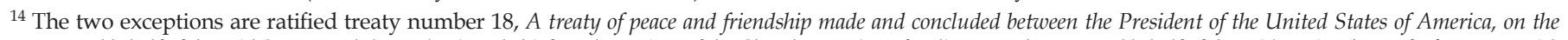
part and behalf of the said States, and the undersigned chiefs and warriors of the Cherokee Nation of Indians, on the part and behalf of the said Nation (Kappler's Treaty with the Cherokee, 1791, 1904b, pp. 29-33, http://digital.library.okstate.edu/kappler/Vol2/treaties/che0029.htm ) at 7 Stat. 39, and ratified treaty number 32, A treaty of limits between the United States of America and the Creek Nation of Indians (Kappler's Treaty with the Creeks, 1802, pp. 58-59, http:/ / digital.library.okstate. edu/kappler/Vol2/treaties/cre0058.htm ) at 7 Stat. 68. Each of these two Statutes documents has an "L.S." notation (also found in Kappler's texts). 
would, for example, include the Treaty with the Iowa, 1837 (pp. 500-501， http://0-digital.library.okstate.edu.library.unl.edu/ kappler/Vol2/treaties/iow0500.htm - “Joshua Pilcher and the undersigned chiefs and delegates of said Indians have hereunto set their hands"). Kappler did not assign a signature indicator to twenty of these 244 total documents.

- An effort by Kappler, however, to impute a locus sigilli to the signatures, based on these phrases from the texts of the Statutes, seems a bit too adventurous. Rather, it would have been more prudent for a Clerk of a Senate Committee, directed to assemble a portion of the law of the land, to look at the original treaty document. As an attorney, Kappler no doubt would have wished to be as inclusive as possible, but if the contracts themselves were at hand-as Deloria and DeMallie imply-then corrections to any potential locus sigilli shortfalls would have fared better if they were based upon the use of the physical evidence provided by the original treaties themselves, and not just upon their transcriptions into the Statutes. The almost total absence of such marks in volume 7 of the Statutes might have been an additional stimulus for Kappler to reexamine the initial instruments.

Another document parameter found at the end of 226 of the 228 pertinent Statutes at Large texts in volume 7, and perhaps employed by Kappler to assist his decisions, is the array of statements that denote "To the Indian names are subjoined a mark and seal." ${ }^{15}$ The term "seal" was not always present in these remarks. The abundance of the "signed and sealed" and of these "subjoined" comments may have been adequate evidence for Kappler to adjust this series of documents within his collation, by adding one of the two signature indicators.

Overall, there are 237 incidences of a "subjoined" statement in the full array of the 361 treaties; the remaining eleven examples are in Statutes volumes $9(N=9)$ and $10(N=2)$. The substantial limitation with this scenario, however, is that the subjoined remarks refer only to Indian participants, so assigned signature marks would only have been properly appended to their names, and not to those of federal government participants.

Finally, the count of the loci sigilli contained in the images on the National Archive microfilm numbered 256, or $71 \%$ of all relevant instruments. The images of this inventory show now that it might have been somewhat difficult to read some of these individual documents. ${ }^{16}$ Their visual states suggest that some of these had degraded by the time they were filmed in the 1960s; some perhaps even earlier when Kappler might have examined them a century ago. It is possible, as well, that some seals have been lost over time and so have gone unrepresented in this microfilm collection. At the same time, these conditions hint that earlier transcriptions of treaties published in the Statutes at Large-some promptly accomplished in the same year as their signing, and certainly by staff who were accustomed to the writing style of the time-were probably quite accurate reproductions of these transactions. Today, these microfilmed images additionally provide a glimpse of the original document, absent any subsequent handling by Congress, so the signatures, the pictographs (unfortunately absent from both Kappler's and the Statutes), and the true sense of the signing event are still available through this resource. The substantial changes by Congress to many parameters of these transactions make these poor conduits of the final law of the land. It would seem fitting, then, for a conscientious compiler to look at both the Statutes at Large for a perspective of the final, legally accepted statements, as well as the original transactions for any useful confirmations-such as the practice of the loci sigilli-that they might provide. The focus on acting as a "conscientious compiler" is not an idle statement. During the Senate debate in 1902 on the resolution to create Indian Affairs, Senator Eugene Hale (Rep.-Maine) declared:

"It has been my observation that pretty much everything of this kind in the way of a special collection of statutes relating to a particular matter has resulted in the clerk of some committee dumping together all the statutes, all the Executive orders, and pretty much everything pertaining to the bureau or the department or the subject, and instead of being a work of advantage to anybody it only adds confusion to confusion."

He further stated, "a good, well-edited, well-indexed document might be very valuable, and the index is the most important part of it all" (Compilation on Indian Affairs, 1902b, p. 5664). The Senator demanded that Senator William Morris Stewart (Rep.-Nevada) supervise the endeavor that he was proposing: "I wish to know if the Senator is prepared to say that he will look after this work." The "clerk" in this situation turned out to be Stewart's protégé, Charles J. Kappler, and the final index of the original, 1903 second volume was substantial, subtending two dozen pages. The 1904 version added another half page.

\section{The underlying rationale}

The compilers of the Statutes at Large used the original treaties as the very foundation of the reproduction of these documents. Kappler's task was, in essence, to deliver to the Senate an omnibus of these instruments from ten volumes of the Statutes. There is thus a reasonable expectation that there should be highly correlated comparisons between the contents of the original transactions and their appearance in the Statutes; these same dealings and Kappler's texts; and the specific treaty entries found in the Statutes and those in volume 2 of Indian Affairs. This latter state would be especially so if Kappler, in his turn, merely copied the Statutes and did not choose to examine the initial accords. In the case where Kappler might have taken for completeness an additional editorial step-here, in order to reconfirm the Statutes' signature sections during the development of his own version of these materials then the initial recognized sources would have been the most suitable error-free means for this information.

In a perfect world, the signed instruments in this scenario would serve as the paragon to which all other copies or reproductions must adhere. This would be an environment in which all the original loci sigilli contained in the treaty documents were reliably transcribed into the corresponding Statutes at Large texts; it would be a situation in which there would be no errors of superfluous or of absent notations. In a traditional $2 \times 2$ table that assembled the counts of these paired events, this specific condition would yield a table configuration of two occupied and two empty cells. The two engaged cells would indicate the intersections of the co-presencesand of the appropriate co-absences - of the loci sigilli in the original treaty documents and in the parallel Statutes at Large passage. The table's pair of vacant cells would confirm that the reproduction had been flawless, that there were no incidences of a locus sigilli in any of the treaties that the Statutes had failed to echo, or that there was a stray indicator that was mistakenly added to the Statutes when no such companion notation appeared in the treaty document.

In a similar manner, if the correspondence between the legitimate presence or absence of loci sigilli in the treaties and in Kap-

${ }^{15}$ Ratified treaty number 25, the Treaty with the Creeks, 1796 (Kappler, 1904b, pp. 46-50, http:/ /0-digital.library.okstate.edu.library.unl.edu/kappler/Vol2/ treaties/cre0046.htm), and ratified treaty number 161, the Treaty with the Menominee, 1831 (pp. 319-323, http:/ /0-digital.library.okstate.edu.library.unl. edu/kappler/Vol2/treaties/men0319.htm) are the two volume 7 documents without this "subjoined" statement. Their "[L.S.]" indicators are preserved in both of Kappler's texts.

${ }^{16}$ The variability is considerable. Visual inspection at the National Archives of the original ratified treaty number 28 and 44 that only appeared in the American State Papers, and the Treaty of Fort Laramie with Sioux, etc., 1851 revealed that the substrate of these three documents is still very sturdy and has maintained its pen-and-ink data very well over the last 150 to 200 years, but others are far more fragile. 
pler's collation was perfect and recorded in another $2 \times 2$ table, the same count configuration would emerge. Further, and of special importance in this analysis, a pristine transcription by Kappler of the treaty passages in that Statutes at Large perfect copy would yield a third output table, with the identical counts for the indicators. In this study of 361 relevant documents, the two "perfect" loci sigilli count tables for the treaties - Statutes and for the treaties-Kappler pairings would each have just two occupied cells, announcing the intersection of 256 "present-present" and of 105 "absent-absent" notation events that actually exist in the texts of the original treaties.

Any transcription errors-relative to the contents of the fundamental instruments-that were either caused by the mistaken absence of, or through the spurious creation of unwarranted, signature notations in the reproduction of the Statutes at Large, or in the content provided by Kappler, would begin to diminish the counts in the corresponding table's occupied cells. Error count(s) that emerged to mirror these inconsistencies would spawn scores that would populate one and/or the other of the two originally empty cells.

In real life, these faults did surface, with the compilers of both the Statutes and of Kappler's Treaties volume either injecting extraneous loci sigilli or failing to report those truly present in the original documents. Table 1, for example, shows that the Statutes hold two treaties now with loci sigilli that were in fact not present in those primary contracts. The table also illustrates that the Statutes failed to report properly 155 such indicators that were actually contained within the real transactions. Kappler's collation initiated similar transcription errors, confirmed by the counts recorded in Table 2 that denote 17 extra marks that were speciously assigned, and the absence of 24 actually present ones that were missed during transcription. It is these transcription data, of the correct and the incorrect assignments of appropriate loci sigilli from the treaties to the Statutes and to Kappler's ensemble, that are under consideration here.

\section{Statistical testing and results}

Siegel and Castellan (1988, p. 6) proposed that "[t]o reach an objective decision as to whether a particular hypothesis is confirmed by a set of data, we must have an objective procedure for either rejecting or accepting that hypothesis." Analysis by nonparametric means is the most appropriate method for binary data of this sort, and they described the phi coefficient $\left(r_{\Phi}\right)$ for $2 \times 2$ tables as "a measure of the extent of association or relation between two sets of attributes measured on nominal scale, each of which may take on only two values" (p. 232). The null hypothesis under such conditions proposes that the two variables that populate the table are independent. The significance of a computed $r_{\Phi}$ may be tested using the chi-square statistic $\left(X^{2}\right)$, with one degree of freedom (1 d.f.) (pp. 232-235).

Two phi coefficient tests were performed. The first assessment compared the corresponding presence of an "[L.S.]" or "[SEAL]" indicator, in the 361 treaty texts of the Statutes at Large, with those of the microfilm images of Ratified Indian Treaties, 1722-1869. Table 1 shows the counts obtained in this comparison. The resulting correlation coefficient, $r_{\Phi}=0.38$ with a significant $X^{2}$ of 51.48 ( 1 d.f., $p<1 \%$ ), suggests that the presence of loci sigilli in the two sources is highly correlated.

A second test was conducted-similar to the first-for the same documents, between the data acquired from Kappler's entries and those in the Ratified Indian Treaties films; Table 2 presents these numbers. Here, the correlation $r_{\Phi}=0.73$ also yields a significant result $\left(X^{2}=192.78,1\right.$ d.f., $\left.p<1 \%\right)$, an outcome that supports a claim that the occurrence of the marks in these two collected works is highly correlated. The findings, then, from these two analyses forcefully lead to the rejection of the null hypotheses that picture independence between these pairs of variables, and clearly reinforce the initial expectation of strong correlations for these corresponding uses of the loci sigilli data.
Table 1. Counts of corresponding loci sigilli in the texts of American Indian treaties in the Statutes at Large compared to those in the texts of the original instruments in the Ratified Indian Treaties collection.

\begin{tabular}{lllll}
\hline & & \multicolumn{2}{l}{ Ratified Indian treaties } \\
\cline { 2 - 4 } & & Present & Absent & \\
\hline \multirow{2}{*}{ Statutes at Large texts } & Present & 101 & 2 & 103 \\
& Absent & 155 & 103 & 258 \\
& & 256 & 105 & 361 \\
\hline
\end{tabular}

A perfect reproduction of the presence and of the absence of loci sigilli found in all treaties would yield scores of 256 and 105 in the "Present-Present" and the "Absent-Absent" cells, respectively.

Table 2. Counts of corresponding loci sigilli in the texts of Kappler's collection of American Indian treaties compared to those in the texts of the original instruments on the Ratified Indian Treaties microfilm.

\begin{tabular}{lllll}
\hline & & \multicolumn{2}{l}{ Ratified Indian treaties } \\
\cline { 3 - 3 } & & Present & Absent & \\
\hline Kappler texts & Present & 232 & 17 & 249 \\
& Absent & 24 & 88 & 112 \\
& & 256 & 105 & 361 \\
\hline
\end{tabular}

The ideal transcription scores projected for Table 1 would be expected here as well.

Table 3. Counts of the correct and incorrect loci sigilli assignments in Kappler's collation and in the Statutes at Large, derived from the data in Table 1 and Table 2, relative to those indicators in the Ratified Indian Treaties microfilm's original documents.

\begin{tabular}{lllll}
\hline & & \multicolumn{2}{l}{ Ratified Indian treaties } & \\
\cline { 3 - 5 } & & $\begin{array}{l}\text { Correct } \\
\text { indicator }\end{array}$ & $\begin{array}{l}\text { Incorrect } \\
\text { indicator }\end{array}$ & \\
\hline Loci sigilli counts & Kappler & 320 & 41 & 361 \\
& Statutes & 204 & 157 & 361 \\
& 524 & 198 & 722 \\
\hline
\end{tabular}

A score of 361 in the "Correct indicator" cell for both collections would confirm errorless transcription from the treaties.

The lower correlation value derived in the first test, however, is a consequence of the Statutes's error to mirror correctly the contents of the original documents. In comparison, Table 1 exhibits 157 indicator faults (i.e., 155 "absent-present" + 2 "present-absent" events) in the contrast made between the Statutes at Large texts and those of the Ratified Indian Treaties images. Table 2 shows that only about a quarter as many locus sigilli mistakes - 41 (24 "absent-present" + 17 "present-absent")- occurred in the correspondence between Kappler's work and the primary materials.

As a final step, a $X^{2}$ test was conducted to examine this error rate disparity, where the null hypothesis posits no difference between the two rates. Table 3 holds the counts of the correct and incorrect indicator assignments found in the Treaties volume and in the Statutes at Large, with respect to the observed presence or absence of these marks recorded from the original treaty images on the Ratified Indian Treaties microfilm. The "Correct indicator" score for Kappler's data consists of the addition of the 232 "presentpresent" and the 88 "absent-absent" scores from Table 2. The "Incorrect indicator" count of 41 is derived from the 24 missed and the 17 incorrectly supplied loci sigilli values. The equivalent components for the Statutes half of Table 3 were developed from the Table 1 data. The test result, $X^{2}=93.64$, advocates that, at a significance level of $1 \%$, the null hypothesis should be rejected, and that there is substantial evidence to show that Kappler was more accurate at correctly reporting proper loci sigilli from the original treaties than were the compilers of the Statutes at Large. The cell counts in Table 3 announce this result: Kappler correctly indicated 320, versus just 204 by the Statutes, of the 361 expected notations from the original, negotiated instruments. 


\section{Conclusions}

There is no unassailable way to confirm the course that Charles J. Kappler took to assemble Indian Affairs: Laws and Treaties, especially the texts of the second or Treaties volume that were of immediate interest to the Senate. In spite of this shortfall, it is abundantly clear that the signature indicators "[L.S.]" or "[SEAL]" have been reliably conveyed from the original transactions to the texts found in the Statutes at Large and-consistently communicated even more so-to those in Treaties. This dependability indicates a successful attempt on the part of the compilers of the original Statutes to transfer the outcomes of these matters as the fundamental aspects of the laws of the land, but this later textual faithfulness shows an even more considerable degree of attention paid to these documents by Kappler. This focus on detail is reconfirmed by the contents of his third, fourth, and fifth volumes of Indian Affairs, created long after he had left government employment and had began to practice law, yet accepted by Congress and published as part of the United States Congressional Serial Set (1913, 1929, and 1941). If Congress had found the earlier Laws and Treaties volumes lacking - as Senator Hale had originally feared - then these three additional accumulations would never have appeared.

The notion that there were other available options or modes to help assemble the treaty collation in Indian Affairs is weak. The use of the "signed and sealed" closing remarks to determine signature validation was certainly possible and may have been associated with the appearance of signature markers in Kappler's work. However, the administrative necessity for him to locate first such remarks within each of the Statutes texts, and then to base on those inspections the inclusion of a locus sigilli indicator in Treaties, suggests a rather precarious route. Alternatively, the use of the "subjoined" note-found at the bottom of the treaties in volume 7 (and elsewhere) of the Statutes - to aid the determination of whether the document was indeed signed and sealed, seems to be an unnecessary exercise, given that the signature indicators were right there-just above each "subjoined" statement - on the Statutes page. More difficulty arises with this proposal when it is recalled that the "subjoined" comments pertained only to Indian signatories, that these notes appeared overwhelmingly only in volume 7 , and thereby, provided information for only about two-thirds of the projected treaties.

The originally created transactions hold much of the same data and, while they may not contain in many cases the final legally recognized text, they do hold other important information as well, such as the signature validations that the seals provided. Kappler could not have assembled an appropriate collation of acknowledged American Indian treaties by disregarding the Statutes at Large. Nevertheless, it would have been improbable for the texts in his Treaties volume of Indian Affairs to have loci sigilli in such trustworthy accord with the signature sections of the original documents if he had not used these very materials to confirm indicator presence. The Statutes at Large just did not have this information to the same degree that Kappler reported throughout his collection.

The outcome of this analysis argues strongly that Deloria and DeMallie were mistaken; Kappler did not "simply [take] several filing drawers filled with documents to the printer." Senator Hale had demanded, in response to Senator Stewart's initial resolution in 1902, that Congress should receive an ensemble of American Indian treaties negotiated with the federal government in "a good, well-edited, well-indexed document" (Compilation on Indian Affairs, 1902b, p. 5664). This stipulation empowered Kappler to create a compilation in 1904 that he believed was "as perfect as practicable" (Kappler, 1904a, p. iii). The results of this study sustain the opinion that he achieved that goal by carefully examining the relevant Statutes at Large as well as the original, physical treaties themselves during this process. It appears now that, through his judgment and guidance as Clerk of the Senate Committee on Indian Affairs, the contents of both sources were integrated into a final collection that not only preserved more fully these legal mate- rials, but also delivered them to Congress in a more complete and useful version than had been previously available.

\section{Acknowledgments}

We thank Michael Black of the Department of Statistics at the University of Nebraska-Lincoln for his statistical advice during the preparation of this article. We also acknowledge Father Francis Paul Prucha, who offered helpful remarks that made this article more complete.

\section{References}

American State Papers: Indian Affairs, vol. 1, 1832 American State Papers: Indian Affairs, vol. 1, (1832). Washington, DC: Gales and Seaton.

Bernholz and Holcombe, $2005<$ C. D. Bernholz and S. L. Holcombe, The Charles J. Kappler Indian Affairs: Laws and Treaties Internet site at the Oklahoma State University, Library Collections, Acquisitions, and Technical Services 29 (2005), pp. 82-89.

Bernholz and Weiner, $2008<$ C. D. Bernholz and R. J. Weiner, The world of Charles J. Kappler: A digital portrait, Legal Reference Services Quarterly 27 (2008), pp. 377-383.

Compilation of All the Treaties Between the United States and the Indian Tribes Now in Force as Laws, $1873 \triangleleft$ A Compilation of All the Treaties Between the United States and the Indian Tribes Now in Force as Laws, (1873). Washington, DC: Government Printing Office.

Compilation on Indian Affairs, 1902a 4 Compilation on Indian Affairs, Congressional Record 35 (1902), p. 5619.

Compilation on Indian Affairs, 1902b 4 Compilation on Indian Affairs, Congressional Record 35 (1902), pp. 5664-5665.

Deloria and DeMallie, $1999<$ V. Deloria and R. J. DeMallie, Documents of American Indian Diplomacy: Treaties, Agreements, and Conventions, University of Oklahoma Press, Norman, OK (1999), pp. 1775-1979.

Evans', 1797 Evans' Lessee v. Short, 1 Del. Cas. 135 (1797).

Farnsworth, 1990 E. A. Farnsworth, Contracts (2nd ed.), Little, Brown and Co, Boston, MA (1990).

Halford, 1901 Halford, A. J. (1901). Official Congressional directory for the use of the United States Congress. First edition. Corrected to December 5, 1901. Senate. 57th Congress, 1st session. Senate Document No. 4, pt. 1-3 (Serial Set 4221). Washington, DC: Government Printing Office.

Holcombe, 2000 Holcombe, S. L. (2000). Bringing Indian Affairs: Laws and Treaties to the World Wide Web. Presented at the Ninth Annual Depository Library Conference, Washington, DC. Online at http://www.fdlp.gov/home/repository/ cat view/177-outreach/97-events/101-depository-library-council-dlc-meetings/124-2000-meeting-proceedings/125-fall-dlc-meeting-arlington-va

Indian Treaties, and Laws and Regulations Relating to Indian Affairs, 18264 Indian Treaties, and Laws and Regulations Relating to Indian Affairs, (1826). Washington, DC: Way \& Gideon.

Indian Treaties and Surrenders, 18914 Indian Treaties and Surrenders: From 1680 to 1890, vol. 1 and 2. (1891). Ottawa: Brown Chamberlin.

Indian Treaties and Surrenders, 19124 Indian Treaties and Surrenders: From No. 281 to No. 48. (1912). Ottawa: C. H. Parmelee.

Kappler, 1896 C. J. Kappler, Entry term minutes, 1863-1938, vol. 8, Records of the District Courts of the United States (RG 21), National Archives and Records Administration, Washington, DC (1896), p. 234.

Kappler, 1901 C. J. Kappler, Entry 61, Attorney rolls, 1790-1961. Records of the Supreme Court of the United States (RG 267), National Archives and Records Administration, Washington, DC (1901).

Kappler, 1903a Kappler, C. J. (1903a). Indian affairs. Laws and treaties, vol. 1. Statutes, executive orders, proclamations, and statistics of tribes. Senate. 57th Congress, 1st session. Senate Document No. 452, pt. 1 (Serial Set 4253). Washington, DC: Government Printing Office. 
Kappler, 1903b \ Kappler, C. J. (1903b). Indian affairs. Laws and treaties, vol. 2. Treaties. Senate. 57th Congress, 1st session. Senate Document No. 452, pt. 2 (Serial Set 4254). Washington, DC: Government Printing Office.

Kappler, 1904a. Kappler, C. J. (1904a). Indian affairs. Laws and treaties, vol. 1. Laws. Senate. 58th Congress, 2nd session. Senate Document No. 319, pt. 1 (Serial Set 4623). Washington, DC: Government Printing Office.

Kappler, 1904b 4 Kappler, C. J. (1904b). Indian affairs. Laws and treaties, vol. 2. Treaties. Senate. 58th Congress, 2nd session. Senate Document No. 319, pt. 2 (Serial Set 4624). Washington, DC: Government Printing Office.

Kappler, $1913 \varangle$ Kappler, C. J. (1913). Indian affairs. Laws and treaties, vol. 3. Laws. Senate. 62nd Congress, 2nd session. Senate Document No. 719 (Serial Set 6166). Washington, DC: Government Printing Office.

Kappler, $1929 \varangle$ Kappler, C. J. (1929). Indian affairs. Laws and treaties, vol. 4. Laws. Senate. 70th Congress, 1st session. Senate Document No. 53 (Serial Set 8849). Washington, DC: Government Printing Office.

Kappler, 19414 Kappler, C. J. (1941). Indian affairs. Laws and treaties, vol. 5. Laws. Senate. 76th Congress, 3rd session. Senate Document No. 194 (Serial Set 10458). Washington, DC: Government Printing Office.

Moore v. United States, 1897 Moore v. United States, 32 Ct. Cl. 593 (1897).

National Archives of Canada, 1997 National Archives of Canada. (1997). Finding Aid/Instrument de Recherche No. 2122: MG 19, F 35 - Superintendent of Indian Affairs. Accessed on 6 March 2009 at http://data2.archives.ca/pdf/pdf001/p000000646.pdf

New Lawyers Admitted to Bar, 1896 New Lawyers Admitted to Bar, The Washington Post (1896) 13 December 1896, 14.

Norton, $1928 \triangleleft$ R. F. Norton, A Treatise on Deeds (2nd ed.), Sweet \& Maxwell Ltd, London (1928).

Ratified Indian Treaties, 1722-1869, $1966<$ Ratified Indian Treaties, 1722-1869, (1966). Washington, DC: National Archives and Records Service.

Roy v. United States and the Ogallala Tribe of Sioux Indians, 1910 4 Roy v. United States and the Ogallala Tribe of Sioux Indians, $45 \mathrm{Ct}$. Cl. 177 (1910).
Siegel and Castellan, $1988<$ S. Siegel and N. J. Castellan, Nonparametric Statistics for the Behavioral Sciences, McGraw-Hill, New York (1988).

Treaties Between the United States of America and the Several Indian Tribes, 18374 Treaties Between the United States of America and the Several Indian Tribes, From 1778 to 1837. (1837). Washington, DC: Langtree and O'Sullivan.

Treaties, laws, etc., relating to Indian Affairs, 1903a 4 Treaties, laws, etc., relating to Indian Affairs, Congressional Record 36 (1903), p. 2299.

Treaties, laws, etc., relating to Indian Affairs, 1903b 4 Treaties, laws, etc., relating to Indian Affairs, Congressional Record 36 (1903), p. 2543.

Treaties, laws, etc., relating to Indian Affairs, 1903c 4 Treaties, laws, etc., relating to Indian Affairs, Congressional Record 37 (1903), p. 290.

Treaties, laws, etc., relating to Indian Affairs, 1903d 4 Treaties, laws, etc., relating to Indian Affairs, Congressional Record 37 (1903), p. 523.

Walker, 19804 D. M. Walker, The Oxford Companion to Law, Clarendon Press, Oxford (1980).

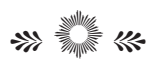

Charles D. Bernholz is the Government Documents Librarian at the University of Nebraska-Lincoln. He has a BA from Northeastern University; an MA from the University of Guelph; and an MLS from the State University of New York at Buffalo. His research interests focus upon treaties created by the Indian Nations and the governments of North America, and upon the development of federal Indian law in the U. S. and in Canada.

Sheryl Heidenreich is Interlibrary Loan and Document Delivery Coordinator and Reference Librarian at Calvin T. Ryan Library, University of Nebraska at Kearney. She has a BS from the University of Nebraska and an MLIS from Dominican University. 